\title{
DEVELOPMENT OF THE RECTUM-TESTIS TEMPERATURE DIFFERENCE IN THE POST-NATAL RAT
}

\author{
MARTTI KORMANO \\ Department of Anatomy, University of Helsinki, \\ Siltavuorenpenger, Helsinki, and Research Laboratory of the \\ Sauna-Seura, Helsinki, Finland \\ (Received 24th October 1966)
}

\begin{abstract}
Summary. The development of the temperature difference between the rectum and testis has been studied in 20-, 25-, 30- and 35-day-old as well as adult rats. Temperatures were recorded with thermocouple needles without anaesthesia. The temperature difference was approximately $3.5^{\circ} \mathrm{C}$ in the adult and 35-day-old animals. The difference was about $2^{\circ} \mathrm{C}$ in the 25 - and 30 -day-old rats and about $1^{\circ} \mathrm{C}$ in the youngest ones. The three younger groups $(20,25$ and 30 days) had significantly higher intratesticular temperatures than the adult rats. In the young rats variations in body temperature between $35.6^{\circ} \mathrm{C}$ and $38.4^{\circ} \mathrm{C}$ did not significantly affect the rectum-testis temperature difference. In the adult rats, the difference began to increase when the rectal temperature rose above $37.6^{\circ} \mathrm{C}$. The relationship of developing temperature difference to the onset of endocrine puberty, functional maturity of the seminiferous tubules and development of the scrotal sac is discussed.
\end{abstract}

\section{INTRODUCTION}

The difference in temperature between the mammalian testis and the rectum or abdominal cavity is well documented; this difference is maintained by the scrotum and vascular cooling mechanisms (Phillips \& McKenzie, 1934; Harrison \& Weiner, 1949; Dahl \& Herrick, 1959; Waites \& Moule, 1961). A scrotal location is, indeed, of vital importance to the testis, because even vascular heat exchange can cool the testes only if heat is being lost through the scrotum (Waites \& Moule, 1961). On the other hand, evidence is accumulating from both experimental (Dahl \& Herrick, 1959) and some clinical (see Brown, Dubin \& Hotchkiss, 1967) observations that the scrotal location of the testes is unable to keep them cool enough, if vascular heat exchange mechanisms are failing.

Numerous investigators have registered intratesticular temperatures in adult mammals, including the rat (Esser, 1932; Imig, Thompson \& Hines, 1948; Harrison \& Weiner, 1948; Elfving, 1950; Maekawa, Tsunenari \& Yamamura, 1965). The published values for the rat vary from $29^{\circ} \mathrm{C}$ to $35^{\circ} \mathrm{C}$. In recent studies a difference of from $3^{\circ} \mathrm{C}$ to $5^{\circ} \mathrm{C}$ between abdominal and testicular 
temperatures has been reported (Elfving, 1950; Maekawa et al., 1965). This temperature difference seems to be essential for normal spermatogenesis, and it must apparently be established before the puberal development of germ cells. However, there are so far no investigations concerning the intratesticular temperature and the thermo-regulatory mechanisms during the post-natal life of the rat. On the other hand, the general puberal development of the male rat has been carefully recorded, including the development of the scrotal sac at the age of 9 weeks as a receptacle for the descending and growing testis (Andrews, 1940).

In the present work testis temperatures have been studied through the postnatal prepuberal life of the rat, and the development of the temperature difference between rectum and testis correlated with the onset of other manifestations of puberty.

\section{MATERIAL AND METHODS}

\section{Animals}

Altogether thirty-one white male rats of the Sprague-Dawley strain were used. Eleven of them were adults, 2 to 6 months of age, weighing 250 to $400 \mathrm{~g}$. The series of post-natal prepuberal animals consisted of 20-, 25-, 30- and 35-dayold rats; their number was $4,4,4$ and 8 , respectively. The rats were reared in constant conditions and received an unrestricted diet of rat cubes and water. The young males were weaned at the age of 1 month.

\section{Temperature recording}

The temperatures were measured with copper-constantan thermocouples and recorded automatically at intervals of $1 \mathrm{~min}$ with a Honeywell 12-point potentiometer with the aid of a Leeds and Northrup d.c.-amplifier. The thermocouples for intratesticular measurement were mounted in the tips of 17-gauge hypodermic needles. The reference junctions were immersed in a thermostatically controlled container. In addition, an external mercury-in-glass thermometer reference was used. Calibration and tests made between and during the experiments established an accuracy of within $0.1^{\circ} \mathrm{C}$. The laboratory air temperature $\left(22\right.$ to $23^{\circ} \mathrm{C}$ ) was measured with a standard mercury-in-glass thermometer.

\section{Experimental procedure}

During short ether anaesthesia the inguinal skin was pierced with two syringes containing thermocouples, one for each testis. From the inguinal region the thermocouples were directed into the testes, previously gently pushed into the scrotum, and fixed with two small sutures to the abdominal skin. The rectal thermocouple was pushed to a depth of $3 \mathrm{~cm}$ in adult animals and proportionally less in smaller rats. When all three thermocouples had been inserted, anaesthesia was discontinued and the animal allowed to wake up in its litter. If necessary, pentobarbitone sodium ('Nembutal'), 5 to $10 \mathrm{mg} / \mathrm{kg}$, was given intraperitoneally to prevent excessive movement. To procure more rapid attainment of a normal range of body temperature after anaesthesia, a lamp 
was kept over the cranial part of the animal until a rectal temperature of about $37^{\circ} \mathrm{G}$ was reached.

All the temperatures, including the reference ones, were recorded throughout the procedure and for periods ranging from $40 \mathrm{~min}$ to $3 \mathrm{hr}$ afterwards. At the end of the recording the animals were killed, and the scrotum opened to confirm the position of the needles. At the end of the standard procedure, some animals (four adults, three 35-day-old rats and one from each younger animal group) were subjected to heating experiments to test the effectiveness of their general temperature regulation, as well as the validity of the method.

To evaluate the general puberal development of the animals used, they were weighed; testes and prostate with seminal vesicles were fixed in buffered calcium-formalin and weighed after fixation for about 5 days. The testes were embedded in paraffin wax, cut at $10 \mu$ and stained with haematoxylin-eosin and periodic acid-Schiff methods for microscopic examination.

\section{RESULTS}

\section{General observations}

The rectal temperature of unanaesthetized animals was about $37^{\circ} \mathrm{C}$ at the beginning of the experiment. The youngest animal groups (20 and 25 days) had a labile body temperature showing a constant tendency to fall during the experiment. Ether anaesthesia always caused a rapid drop in the rectal temperature, but the animals recovered rapidly and their rectal temperatures reached the normal range within 10 to $15 \mathrm{~min}$. A sedative dose of Nembutal did not affect the temperatures recorded.

To study the possible effect of external heating on the temperature difference between rectum and testis, testes of two adult and two 35-day-old rats were heated with a lamp for 5 to $10 \mathrm{~min}$. As a result, the intratesticular temperature rose by amounts varying between 1.0 and $3.7^{\circ} \mathrm{C}$, but it was never allowed to increase above the rectal temperature. The re-establishment of the rectumtestis temperature difference is shown in Text-fig. 1, in which the diminution of the temperature difference in each testis caused by heating is taken as $100 \%$. Although the mean elevation of intratesticular temperature produced was $2 \cdot 6^{\circ} \mathrm{C}$, the testes very rapidly cooled back towards their previous temperature, which was mostly regained after about $10 \mathrm{~min}$. Therefore, measurement of the rectum-testis difference (Table 2) was made by including only those sections of the records obtained at least $10 \mathrm{~min}$ after discontinuing external heating of the cranial part of the rat body, so as to allow the possible effect of warming on the testis temperature to disappear.

The necessity of the external position of the testis for maintaining the temperature of the testis was demonstrated by pulling a testis with its thermocouple through the inguinal canal into the abdominal cavity. This caused a rapid (within 2 to $3 \mathrm{~min}$ ) rise from $33^{\circ} \mathrm{C}$ up to $36^{\circ} \mathrm{C}$ in the testicular temperature of an adult rat.

In adult animals it was possible to measure temperatures at different sites within the testis. It was seen that the cranial pole of the testis was somewhat warmer than the caudal pole. The surface of the tunica albuginea was also 
cooler than the deep testicular tissue. In preliminary experiments these differences were always less than $0.5^{\circ} \mathrm{C}$, being much less than the variations between individual animals. In the younger rats, similar measurements were impracticable because of their small testes.

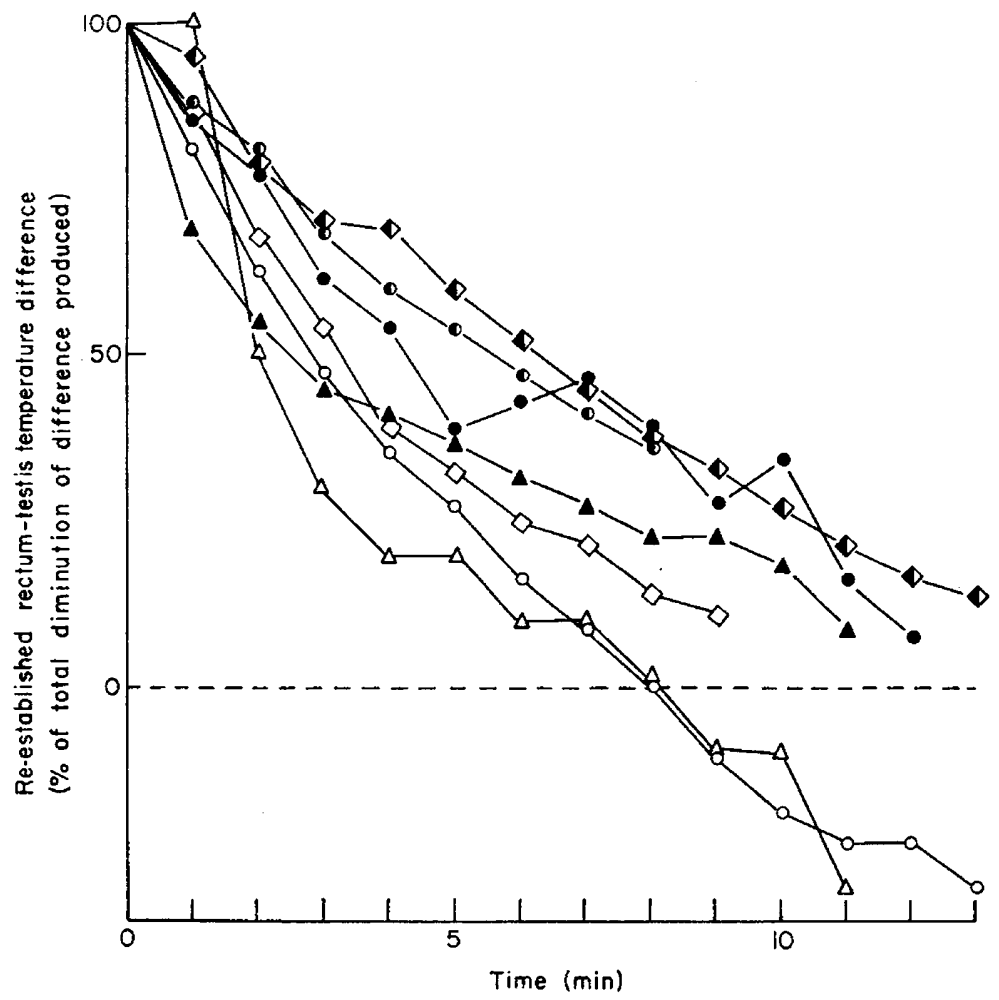

TExT-FIG. 1. Re-establishment of the normal rectum-testis temperature difference after external heating of scrotum in adult and 35-day-old rats.

TABLE 1

WEIGHTS OF THE ANIMALS USED FOR TEMPERATURE MEASUREMENT

\begin{tabular}{|c|c|c|c|c|c|c|c|}
\hline \multirow[t]{2}{*}{$\begin{array}{c}\text { Age } \\
(\text { days })\end{array}$} & \multirow[t]{2}{*}{$\begin{array}{l}\text { No. of } \\
\text { animals }\end{array}$} & \multicolumn{2}{|c|}{ Mean body weight } & \multicolumn{2}{|c|}{ Mean testis weight } & \multicolumn{2}{|c|}{$\begin{array}{l}\text { Mean weight of } \\
\text { prostate-seminal } \\
\text { vesicle complex }\end{array}$} \\
\hline & & $(g)$ & $S D$ & $(m g)$ & $S D$ & (mg) & $S D$ \\
\hline $\begin{array}{c}20 \\
25 \\
30 \\
35 \\
\text { Adult }\end{array}$ & $\begin{array}{l}4 \\
4 \\
4 \\
5 \\
9\end{array}$ & $\begin{array}{r}39.3 \\
58.8 \\
93 \cdot 8 \\
115 \cdot 2 \\
325 \cdot 0\end{array}$ & $\begin{array}{r}3 \cdot 7 \\
7 \cdot 5 \\
13 \cdot 2 \\
16 \cdot 7 \\
59 \cdot 6\end{array}$ & $\begin{array}{r}95 \\
239 \\
358 \\
512 \\
1660\end{array}$ & $\begin{array}{r}11 \\
27 \\
27 \\
33 \\
139\end{array}$ & $\begin{array}{r}73 \\
110 \\
159 \\
216 \\
2994\end{array}$ & $\begin{array}{r}12 \\
27 \\
18 \\
20 \\
370\end{array}$ \\
\hline
\end{tabular}

Puberal development of the rats

The body weights and weights of testes and prostate-seminal vesicle complexes are presented in Table 1. Microscopic examination of the testes was carried out to evaluate the highest developmental stage attained by the germ 
cells in the immature seminiferous tubules. At the age of 20 days, no spermatids were seen in the tubules, primary spermatocytes being in their pachytene phase of development. The first meiotic division had not occurred in any tubules and thus no secondary spermatocytes could be identified. At the age of 25 days, the most advanced tubules contained secondary spermatocytes and numerous dividing spermatocytes could be seen. In the testes of only one animal were spermatids seen in their first four stages of development (Leblond \& Clermont, 1952). In the 30-day animals, numerous tubules contained spermatids, the most advanced being at stages VI to VII (stage VIII in one animal). Many of the advanced spermatids seemed abnormal as compared with the corresponding cells in the adult animals. In the 35-day group, all of the tubules contained spermatids. In this group spermatids at stages X to XIII could be seen, the oldest ones in a degenerate state. In stage XIV tubules, no stage XIV spermatids were identified and, therefore, two generations of spermatids were never seen in the same tubule.

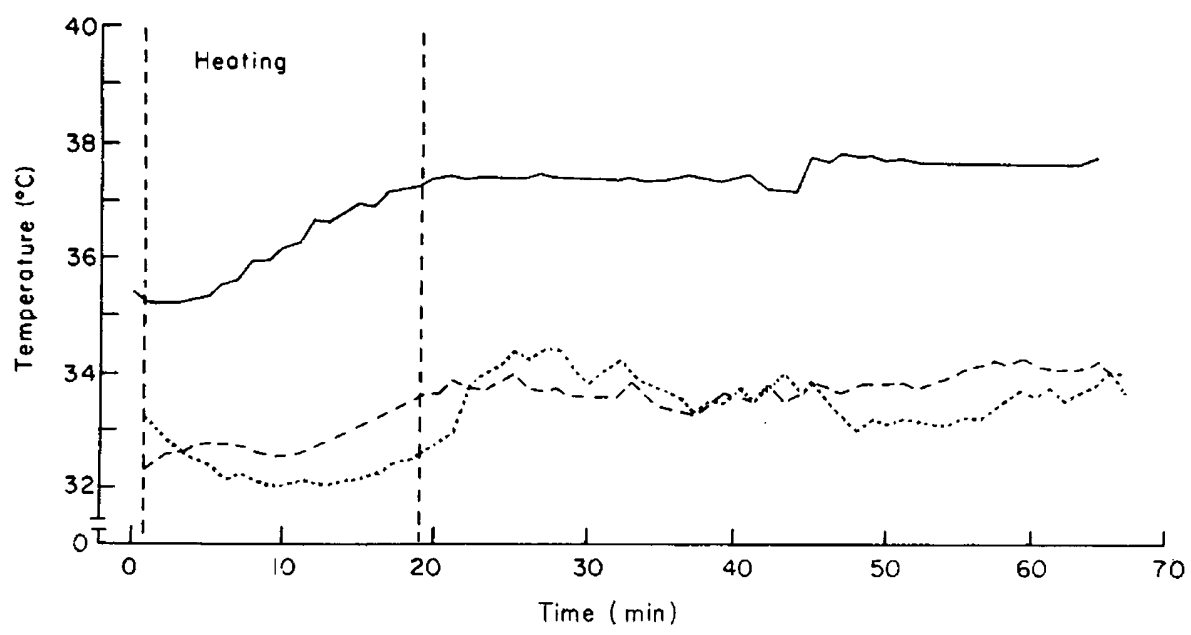

TEXT-FIG. 2. A record of rectal and testicular temperatures in an adult rat, aged 6 months. The temperatures at the beginning of the record are low because of short ether narcosis for insertion of thermocouples. -, Rectum; $\cdots \cdots$, right testis; --, left testis.

\section{Temperature difference between rectum and testis}

The records made it possible to follow the rectum-testis temperature difference for a reasonably long time, during induced changes of body temperature. The mean difference in adult as well as in 35-day-old animals was greater than that in the younger ones, irrespective of the phase of the recording procedure (Text-fig. 2, adult; and Text-fig. 3, 30 days). The temperature difference between the rectum and the testis measured once a minute was averaged for each animal. Table 2 presents the mean values of these differences at a rectal temperature $37 \cdot 2 \pm 0 \cdot 6^{\circ} \mathrm{C}$. From this material, the four animals used in the testicular heating experiments were omitted, as well as one 35-day-old rat, the record of which did not meet the given requirements for analysis in Table 2.

In the adult and the 35-day-old animals the mean temperature difference was about the same, $3.47^{\circ} \mathrm{C}$ and $3.33^{\circ} \mathrm{C}$, respectively, but individual variations 
were greater in the latter group. In the 30-day-old animals, however, the temperature difference $\left(2.04^{\circ} \mathrm{C}\right)$ was significantly smaller than in the adult group $(P<0.001)$ and slightly smaller than in the 35-day group $(P<0.0125)$. In the 25-day group, the results were essentially similar to those found at 30 days, while the youngest animals ( 20 days) had a mean temperature difference of $1 \cdot 05^{\circ} \mathrm{C}$.

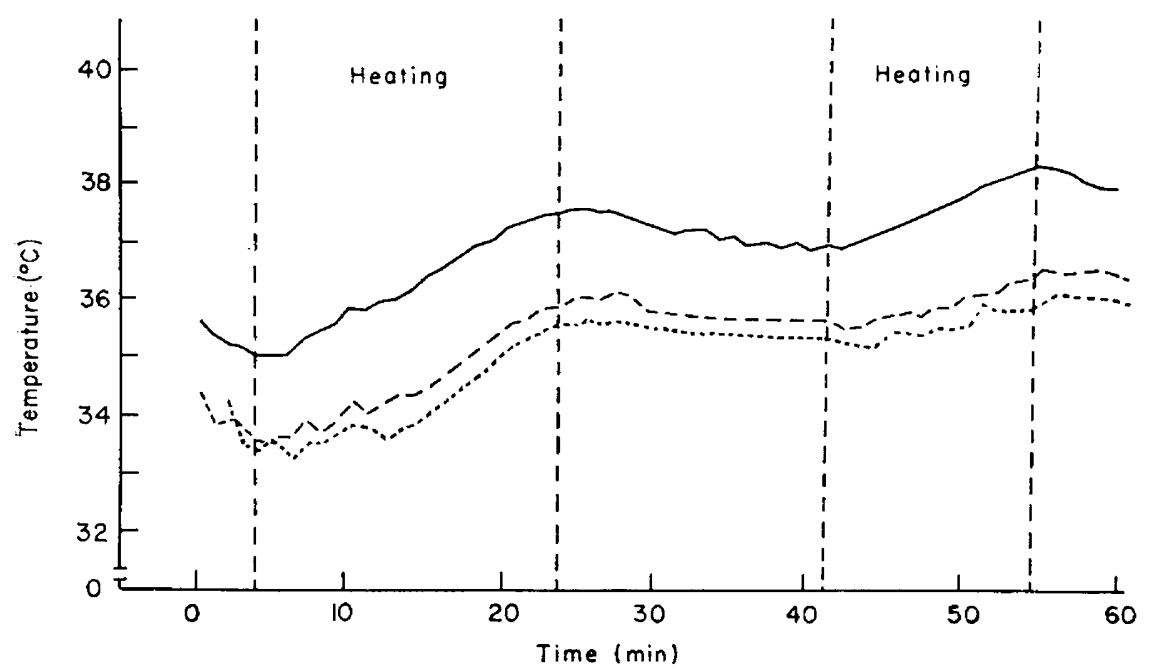

Text-Fig. 3. A record of rectal and testicular temperatures in a 30-day-old rat. Note the small difference between temperatures of rectum and testes. Variations in the body temperature cause no alteration in the mean difference. - , Rectum; $\cdots \cdots$, right testis; -- , left testis.

TABLE 2

REGTUM-TESTIS TEMPERATURE DIFFERENGES IN POST-NATAL RATS AT RECTAL TEMPERATURE $37 \cdot 2 \pm 0 \cdot 6^{\circ} \mathrm{C}$

\begin{tabular}{c|c|c|c|c}
\hline $\begin{array}{c}\text { Age } \\
\text { days })\end{array}$ & $\begin{array}{c}\text { No. of } \\
\text { animals }\end{array}$ & $\begin{array}{c}\text { Mean rectum-testis } \\
\text { difference }\left({ }^{\circ} \mathrm{C}\right)\end{array}$ & $S D$ & $P<*$ \\
\cline { 2 - 4 } 20 & 4 & 1.05 & 0.81 & 0.001 \\
25 & 4 & 1.93 & 0.49 & 0.001 \\
30 & 4 & 2.04 & 0.56 & 0.001 \\
35 & 5 & 3.33 & 0.79 & - \\
Adult & 9 & 3.47 & 0.38 & \\
\hline
\end{tabular}

* Significance of the difference from the adult group.

In individual animals, differences were seen in the temperatures of the right and left testes (see Text-figs. 2 and 3). However, no tendency to a constant temperature difference between the right and left testes was observed.

\section{Effect of body temperature on the intratesticular temperature}

The records led to the expectation that the difference between rectal and testicular temperatures would be little affected by changes in rectal temperature (see Text-figs. 2 and 3). The measurement of values for the mean rectum-testis temperature difference presented in the previous section is also based on this 
expectation, because variation of rectal temperature $\left(37 \cdot 2^{\circ} \pm 0.6^{\circ} \mathrm{G}\right)$ was allowed. To obtain more information about the efficiency of the testicular cooling mechanism, testicular temperatures were further investigated in relation to rectal temperature. The mean temperature values for each testis at rectal temperatures between $35.6^{\circ} \mathrm{C}$ and $38.4^{\circ} \mathrm{C}$, at $0.2^{\circ} \mathrm{C}$ intervals, are presented in Text-fig. 4. In the adult group an elevation of rectal temperature

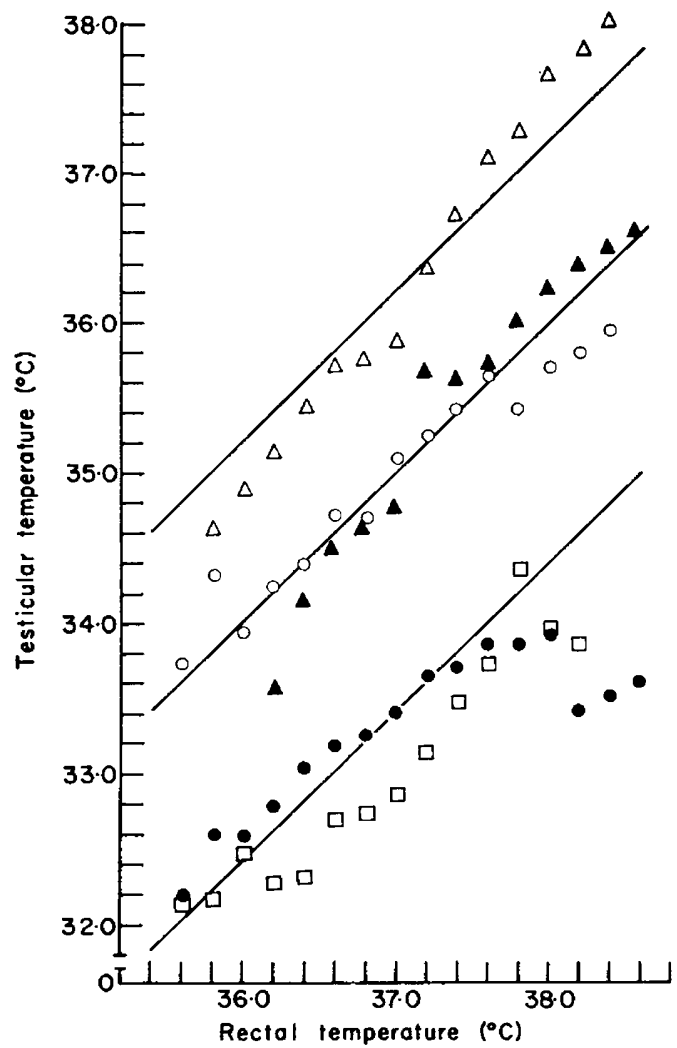

TExT-rig. 4. Correlation of rectal and testicular temperatures in adult (๑), 35-day ( $\square$ ), 30-day $(O), 25$-day $(\Delta)$ and 20-day $(\Delta)$ rats. Each point represents the mean value of the group at a given rectal temperature. Regression coefficients $(b)$ of the different age groups do not differ significantly from 1.0 except in the adult group at rectal temperatures over $37^{\circ} \mathrm{G}$.

was followed by a similar rise in testicular temperature, the difference remaining constant. At rectal temperatures above $37.6^{\circ} \mathrm{C}$, the testicular temperature remained almost constant in spite of rising rectal temperatures. In all the other groups the temperatures of both rectum and testis rose and fell equally. The regression coefficients of the mean values in each pubertal rat group do not differ significantly from $1 \cdot 0$.

\section{DISCUSSION}

Although the body temperature of the rats varied during the experiment between $36.6^{\circ} \mathrm{C}$ and $37.8^{\circ} \mathrm{C}$, the rectal temperature was usually maintained within these limits by animals older than 25 days without external heating. The 
corresponding values of Elfving (1950) for abdominal temperature of the rat are of the same order, but recently Maekawa et al. (1965) reported rectal temperatures of about $36^{\circ} \mathrm{C}$ for adult rats; the exact conditions in which the measurements were carried out are not known, however. The body temperature of a small animal like a rat is naturally subject to variation, and it is difficult to determine the exact normal body temperature of rats of different ages. The present determination of the temperature difference was, therefore, carried out within given rectal temperatures, irrespective of the age of the animal.

Testicular temperature is generally known to fluctuate rapidly in response to external heating or cooling of the scrotum (Moule \& Knapp, 1950; Waites $\&$ Moule, 1961). In the present study, the testicular temperature of the rat, in addition to rapid elevation, also rapidly approached normal values after external heating was discontinued. This capacity has been claimed to be a consequence of the vascular heat exchange mechanism, which enables the temperature of all the testicular tissue to approach that of the inside of the scrotal skin (Waites \& Moule, 1961). The venous portion of the rat testicular vasculature is located entirely on the surface of the testis, just beneath the scrotum, without any direct veins of larger size (Kormano, 1967). The venous blood is, therefore, effectively cooled before it surrounds the warm arterial inflow. As a consequence an artificially elevated intratesticular temperature can be lowered by more than $1^{\circ} \mathrm{C}$ within $2 \mathrm{~min}$ at room temperature (Text-fig. 1). Therefore, the value of the method used earlier by Elfving (1950) for measuring the intratesticular temperature of rats after they had been kept at an environmental temperature of $30^{\circ} \mathrm{C}$ is questionable. The importance of the scrotal location of the testes for their temperature regulation is generally admitted. A constant temperature difference between the rat abdominal cavity and the testis seems to persist even under widely altered environmental temperature conditions (Elfving, 1950). The difference between testicular and body temperatures, although fairly well maintained when the testes were in the scrotum, became rapidly disturbed after the testes with their thermocouples were pushed into the inguinal canal. Because it was impossible to push the testis into the scrotal sac in very young rats, animals less than 20 days old could not be studied.

\section{Temperature difference between rectum and testis}

The temperature difference observed in the present study between the rectum and testis in adult rats (about $3.5^{\circ} \mathrm{C}$ ) is in agreement with earlier observations (Elfving, 1950; Maekawa et al., 1965). However, the very early results published by Esser (1932) and by Imig et al. (1948) give a gradient of 1 to $2^{\circ} \mathbf{C}$ and an intratesticular temperature of $29^{\circ} \mathrm{C}$ respectively, in the rat. The temperature difference in 35-day animals was equal to that in adults, although their testicular size is still much smaller (Table 1). It seems that maximum capacity of an active thermoregulatory mechanism comes into effect at between the 30th and 35 th days of post-natal life. The individual variations in the temperature differences of the 35-day group are probably a reflection of differences in the developmental stage. In fact, these differences were also seen in the microscopic picture of the seminiferous tubules. Another observation also suggests that an 
active cooling system is manifested at this developmental stage. While the scrotum of the 20- and even 25-day animals was considerably hairy and, therefore, unfavourable for heat dissipation, the scrotal skin of 30- and 35-day animals was smoother, there being no striking difference between these two groups. Even the development of the pampiniform plexus did not differ in the 30- and 35-day groups. This suggests onset of some haemodynamic mechanisms in the testis at the age 30 to 35 days, which permits effective heat loss through the scrotum to provide a cool venous outflow from the testes. However, little is known about other mechanisms than the testicular artery-pampiniform plexus system (Cross \& Silver, 1962; Waites \& Voglmayr, 1962, 1963). A striking increase has been observed in the venous network on the surface of the testis between the ages of 30 and 35 days (Kormano, 1967), and this may be an important step towards cooling the returning venous blood more effectively.

\section{Germinal cell development in relation to testicular temperature}

A low temperature in the testis is necessary for normal spermatogenesis because normal body temperature rapidly destroys the germinal epithelium (Moore, 1924). The spermatids are known to be the most sensitive to elevated temperature (Niemi \& Kormano, 1965; Davis \& Firlit, 1966). Mature spermatozoa are first seen in the seminiferous tubules of the rat at the age of about 45 to 48 days (Clermont \& Perey, 1957; Huckins, 1965). Because the spermiogenic part of the spermatogenic cycle of both immature and adult rats lasts 12 to 13 days (Clermont, Leblond \& Messier, 1959; Huckins, 1965), the first spermatids which are able to develop into spermatozoa are produced after the age of 25 days. To prevent these highly sensitive cells from degenerating, a relatively low testicular temperature at this age seems reasonable. The testicular temperature of about $35^{\circ} \mathrm{C}$ at the age of 25 and 30 days seems also to be of importance for the development of the more primitive germ cells. Davis \& Firlit (1966) reported that experimental cryptorchidism at this age causes an arrest of the spermatogenic cycle at the pachytene primary spermatocyte level of development. Anyway, the temperature, which is higher in the immature testis than in the adult, may cause some degenerative changes in the spermatids observed in the present study. These degenerative changes have been carefully described by Allen \& Altland (1952).

\section{Relationship between rectal and testicular temperatures}

The mean rectum-testis temperature difference was seen to be constant in spite of large variations in the rectal temperature. The slight increase in the temperature difference observed at increased rectal temperatures in adult rats may be a manifestation of an activated cooling mechanism. Andrews (1940) reported that the scrotum does not reach complete functional maturity before the age of 9 weeks in the rat. A somewhat different reaction at higher temperatures between adult and 35-day-old animals may result from functional immaturity of the scrotum in the 35-day group, although both groups had a very similar temperature difference at normal rectal temperatures. In most earlier investigations heat has been applied directly to the scrotum or the whole animal has been surrounded by an elevated temperature. In both of these procedures, 
the scrotal-testicular gradient is subjected to abnormal conditions. If only the scrotum of a ram is being heated, the temperature deep in the testis follows variations in the temperature of the scrotal subcutaneous tissue (Moule \& Knapp, 1950; Waites \& Moule, 1961), and the magnitude and direction of vascular heat exchange depends on temperature difference between the body and the scrotum. Elfving (1950), on the other hand, found no change in the internal temperature of the testis as a response to environmental temperatures of $10^{\circ} \mathrm{C}$ and $30^{\circ} \mathrm{C}$. However, the result obtained with elevated temperatures is affected by the rapid cooling of the testis in normal room temperature, as is shown by the present results. In the present study the intratesticular temperature shows the efficiency of the thermo-regulatory mechanism in excluding the warming effect of blood, which flows into the testes and the scrotum. As shown by Text-fig. 4, the gradient is similar over a wide range of body temperature, its magnitude being characteristic of different stages of development of the thermo-regulatory mechanism.

\section{REFERENCES}

Allen, E. \& Altzand, P. D. (1952) Studies on degenerating sex cells in immature mammals. II. Mode of degeneration in the normal differentiation of the definitive germ cells in the male albino rat from age 12 days to maturity. $\mathcal{7}$. Morph. 91, 515.

ANDREws, F. N. (1940) Thermo-regulatory function of rat scrotum. I. Normal development and effect of castration. Proc. Soc. exp. Biol. Med. 45, 867.

Brown, J. S., Dubin, L. \& Horchkiss, R. S. (1967) The varicocele as related to fertility. Fert. Steril. $18,46$.

Glermont, Y., Lebrond, C. P. \& Messier, B. (1959) Durée du cycle de l'épithélium séminal du rat. Archs Anat. microsc. Morph. exp. 48, 37.

Clermont, Y. \& Perey, B. (1957) Quantitative study of the cell population of the seminiferous tubules in immature rats. Am. 7. Anat. 100, 241.

Gross, B. A. \& SILver, I. A. (1962) Neurovascular control of oxygen tension in the testis and epididymis. 7. Reprod. Fert. 3, 377.

DAHL, E. V. \& HERRICK, J. F. (1959) A vascular mechanism for maintaining testicular temperature by counter current exchange. Surgery Gynec. Obstet. 108, 697.

Davis, J. R. \& FirLit, C. F. (1966) The germinal epithelium of cryptorchid testes experimentally induced in prepubertal and adult rats. Fert. Steril. 17, 187.

ELfving, G. (1950) Effects of the local application of heat on the physiology of testis. An experimental study on rats, pp. 104. T. A. Sahalan Kirjapaino Oy., Helsinki.

Esser, P. H. (1932) Über die Funktion und den Bau des Scrotums. Z. mikrosk.-anat. Forsch. 31, 108.

Harrison, R. G. \& WeIner, J. S. (1948) Abdomino-testicular temperature gradients. $\mathcal{F}$. Physiol., Lond. 107, 48P.

HARRISON, R. G. \& WEINER, J. S. (1949) Vascular patterns of the mammalian testis and their functional significance. F. exp. Biol. 26, 304.

Huckins, C. (1965) Duration of spermatogenesis in pre- and post-puberal Wistar rats. Anat. Rec. 151, 364.

Imig, C. J., Thompson, J. D. \& Hines, H. M. (1948) Testicular degeneration as a result of microwave irradiation. Proc. Soc. exp. Biol. Med. 69, 382.

Kormano, M. (1967) An angiographic study of the testicular vasculature in postnatal rat. Z. Anat. Entwickl.- Gesch. (In press).

Leblond, C. P. \& Clermont, Y. (1952) Spermiogenesis of rat, mouse, hamster and guinea pig as revealed by the periodic acid-fuchsin sulfurous acid technique. Am. 7. Anat. 90, 167.

Maekawa, K., Tsunenari, Y. \& Yamamura, Y. (1965) Effect of cadmium administration on intratesticular temperature in the rat. Zool. Mag., Tokyo, 74, 170.

Moore, C. R. (1924) Properties of the gonads as controllers of somatolytic and psychical characteristics. VI. Testicular reactions in experimental cryptorchidism. Am. F. Anat. 34, 269.

Moule, G. R. \& KNAPP, B. (1950) Observations on intra-testicular temperatures of Merino rams. Aust. F. agric. Res. $1,456$.

Niemi, M. \& Kormano, M. (1965) Response of the cycle of the seminiferous epithelium of the rat testis to artificial cryptorchidism. Fert. Steril. 16, 236. 
Phillips, R. W. \& McKenzie, F. F. (1934) The thermo-regulatory function and mechanism of the scrotum. Res. Bull. Mo. agric. Exp. Stn, 217, 1.

Wartes, G. M. H. \& Moule, G. R. (1961) Relation of vascular heat exchange to temperature regulation in the testis of the ram. F. Reprod. Fert. 2, 213.

Wartes, G. M. H. \& Voglmayr, J. K. (1962) Apocrine sweat glands of the scrotum of the ram. Naturc, Lond. 196, 965.

Wartes, G. M. H. \& Voglmayr, J. K. (1963) The functional activity and control of apocrine sweat glands of the scrotum of the ram. Aust. F. agric. Res. 14, 839. 